\title{
Blood on the Cross
}

An ABC Four Corners team investigates allegations about the role of the International Red Cross and the British military in a massacre in the Southern Highlands of Irian Jaya during May 1996. The story of what happened has never been told before.

\section{By MARK DAVIS}

MARK DAVIS: This whole place [Jayapura] is full of Indonesian soldiers and spies and they're not just here to terrorise the locals - they're here to keep information in and foreigners out. I had to leave here 12 months ago when I was being followed day and night. I've returned to complete the story that I began then. It's a story of a massacre, a story that involves not just Indonesians, but Western governments and the International Red Cross, with white soldiers literally carrying out acts of murder.

Map: West Papua (Irian Jaya) showing the locations of Jayapura, Timika and the Southern Highlands.

The Southern Highlands of West Papua or Irian Jaya, one of the planet's last secret places. Neither priest nor profiteer had set foot in these valleys until the 1960s. It's likely that they still contain people and places totally unknown to the outside world. May last year [1998] — reports of starvation have been filtering out of the Highlands. The International Committee for the Red Cross together with the Australian army re dropping food. It's a drought relief program they both claim, "death by El Nino" - but on the ground the hungry and the dying have a different story.

As the Australian army and the International Red Cross deliver their payload across the Highlands, a 16-year-old boy has made an epic journey down from the mountain to the capital, Jayapura. Today he has seen his first electric light, his first car and his first glimpse of the ocean. Until a few months ago he'd 10 PACIFIC JOURNALISM REVIEW 6:1 2000 


\section{BLOOD ON THE CROSS}

never seen an Indonesian soldier, and the first one that he did see tried to kill him.

Papuan Boy: So I ran away into the river and I saw the bullets hit the water. They went zing zing and then I passed out.

DAVIS: This boy and the pastor who found him speak of what is really happening in the Highlands. It's not El Nino which is killing people and destroying crops, it's the Indonesian army: dozens have been killed and tortured, food gardens destroyed, villages burnt to the ground. Entire communities have fled into the jungle and are slowly starving to death. I was forced to abandon my plan to travel into the military zone, but I was able to send my camera in. After some basic lessons I left, and a few months later an extraordinary video arrived in the mail. These are the first images ever broadcast of some of the people that are being hunted across the mountains by the Indonesian military, and the first video of independence leader Kelly Kwalik.

For twenty years Kwalik has moved through these forests, preaching war against Indonesia and the giant Freeport gold mine which had come onto his land. He is probably the most famous man in West Papua, but only one distant image of him had ever been published. Rarely sighted, often rumored to be dead - to many almost a mythical figure.

Kelly Kwalik: Freeport and the Indonesian government regard me as a criminal or a cruel person. This is an absolute lie. The truth is I am a true patriot fighting for my country of West Papua. I regard Freeport and the government and military of Indonesia as criminals, thieves, oppressors, rapists, destroyers of all life and violators of all laws.

DAVIS: Kwalik spoke of a campaign to exterminate his people, a campaign that had began in earnest three years ago with an act of murder by white soldiers - western murderers aided, he believes, by the world's most respected humanitarian organisation.

Kelly Kwalik: The International Red Cross has been used by the military or the Indonesian government.

Papuans (shouting): Freedom! Freedom!

DAVIS: This was the first message he had been able to get out to the world and there was a ring of truth about it. I made arrangements to go back.

Papuans (singing): Oh Mother, I'm going to die. We are going to die. We are going to die.

DAVIS: Getting to see Kwalik and his followers is a story in itself which can't be told. There are several thousand Indonesian troops now stationed in 


\section{MARK DAVIS}

these hills hunting for Kwalik and protecting the Freeport mine. All of the main villages around here are now military hamlets, but there are still about 1000 people who refuse to come in. They call themselves "the outsiders": The Amungme, the Nduga and the Dani - the three main tribes of the Southern Highlands. These people are a mixture of veteran fighters from the Free West Papua Movement, the OPM, and more recent refugees fleeing the Indonesian military and too scared to return to their villages. This camp is their last refuge in the mountains, and their leader is Kelly Kwalik.

Kelly Kwalik: They chased them far into the jungles. It was difficult to get medicines, difficult to get food. So they died because of the illness, starvation and of course being gunned down. So, when Indonesia said they died from drought it was totally a lie. It was a lie. It was said to justify the Indonesian government's wrongdoing.

DAVIS: The people here estimate that 120 tribespeople have been killed and even more died of starvation and disease as the Indonesian Army swept across the mountains in pursuit of these three men - Kelly Kwalik, Daniel Kogoya and Silas Kogoya - each of whom have been hunted for more than twenty years.

Papuans (singing): Be careful or the Javanese will bomb you. Hit by the atom bomb and we die.

DAVIS: In 1977 most of these people had their first introduction to the modern world courtesy of the Indonesian airforce.

Daniel Kogoya: This one was born in the jungle. After the events of that year they ran away and lived in the jungle.

DAVIS: Just eight years after the United Nations had handed West Papua over to the Indonesians there was a series of independence flag raisings in the main towns of the Highlands. The Indonesian response was staggering - they bombed and strafed villages whose loyalties they regarded as suspect.

Daniel Kogoya: Since they were breast feeding until now they've never seen a town.

DAVIS: At least 1000 people were killed, perhaps as many as 5000. Others fled into the forest never to return, not even to visit any government controlled area again.

Daniel Kogoya: All the people of their age have the same story.

DA VIS: During the bombings in 1977, Kwalik joined with Daniel and Silas and attacked Indonesia's single most valuable asset - the Freeport gold and 
copper mine - shutting it down for a week. It was a strike at Indonesia's economic foundation and since then these people have faced a state of continuous war and the world has barely heard about it. Freeport - the biggest gold and copper mine in the world, American owned with the backing of BritishAustralian mining giant, Rio Tinto.

In 1994, twenty civilians were killed or disappeared at the hands of Indonesian troops in and around the mine, and dozens of others were raped and tortured after an independence flag was raised there. The killings continued through the next year. In Kwalik's mind the armies of the world would come to his people's aid if they knew what was happening - if only he had the means of getting his message out. This was the setting when a team of biologists came onto Nduga land in search of uncharted valleys. Kelly, Silas and Daniel had found their outlet to the world.

Silas Kogoya (singing): When the English people came. Remember when. Remember when.

DAVIS: Together with their guides, four Indonesian researchers were kidnapped, four British students, a German and a Dutch couple, Mark and Martha Klein. Martha was three months' pregnant.

Daniel Kogoya: Among the hostages one woman was a bit rude. They wanted to be released very soon.

Silas Kogoya: "Don't letme give birth here." That's what Martha said. She even asked me to kill a pig and cook it for her.

Kelly Kwalik: We took the researchers as hostage because we hadno other way for our cause to be acknowledged.

Mark Davis: Daniel Start was the leader of the British team.

Daniel Start: It was clear they didn't really know what they wanted to do with us, but it was quite soon after that that we realized that we were something very significant to them.

DAVIS: Indonesia's special forces Kopassus were charged with securing the hostages' release. The troops were led by Major-General Probowo, with a team of expert advisers from Holland and particularly Britain.

Ivor Helberg: These tribespeople, their minds wander and you know, total agreement even in a democracy is difficult enough, but you can imagine with these tribal people they could never come to any real conclusion as to what needed to be done.

DAVIS: The British -appointed Military Attaché and SAS veteran Colonel 


\section{'I had always}

returned hostages,

even soldiers. I

caught them, fed

them, looked after

them and took them

back.... The whole

world believes the

hostages were

murdered by OPM.

But we've got

witnesses. Right:'

DANIEL KOGOYA, an

OPM rebel leader

Ivor Helberg to provide specialised assistance and advice to Probowo.

Ivor Helberg: Simply they were illiterate. You're talking about people who are really in the Stone Age - very small, very muscular, very emotive. And we obviously had to treat this situation extremely carefully because these people were perfectly capable of killing.

Daniel Kogoya: But I could not do that. I had always returned hostages, even soldiers. I caught them, fed them, looked after them and took them back.

DAVIS: For four months the Red Cross and others negotiated with Kwalik. Until today the details of those negotiations and the military attack that led to the hostages' release have been murky. The official story goes that eight OPM soldiers were killed in a battle with Kopassus, who rescued the hostages. A battle that reached its climax after two of the Indonesian captives had been executed by the OPM. It is a story that the International Red Cross and the British and Dutch officials who worked with Probowo have never publicly cast doubt upon. A story that seemed to justify Probowo's next mission - a military operation to track down the OPM murderers.

Daniel Kogoya: He [Kelly Kwalik] says that he has read it in the magazine and the whole world believes that the hostages were murdered by OPM. But we've got witnesses. Right.

Silas Kogoya: And also the British hostages were there, the Dutch were also present, weren't they right in front of them?

DAVIS: Daniel Start confirms that the Indonesians were not killed by their OPM captors. The witnesses here reveal they were killed by grieving civilians - friends and relatives of the innocent people who had been murdered days before under extraordinary circumstances - lured to their deaths by a white 
helicopter with a Red Cross flag and gunned down by four or five white people and the Indonesians hiding behind them.

Daniel Kogoya: At first it was Western people, white people. The pilot, and the helicopter were Freeport. I came towards the front and the soldiers came down the other side. They lay down and the shooting started immediately.

DAVIS: These are the first eyewitness accounts of what occurred in the village of Geselema on the 9th May 1996, but it's not just Kwalik's people who testify to it. This month [July 1999] the Institute for Human Rights in Irian Jaya is about to release its account of what occurred in Geselema and they have given me permission to talk with one of their investigators. This man was one of a team who over the past 12 months got behind the military blockade and spoke directly with civilian eyewitnesses.

Institute for Human Rights Investigator: The people were surprised because the Red Cross used to help them, but now they are killing the people.

DAVIS: The statements all confirm a white helicopter with Indonesian soldiers hiding in the back, a Red Cross flag, white people shooting at them and, many of them claim, a white woman whom they'd learnt to trust, Sylvianne Bonadei of the International Committee for the Red Cross. Sylvianne Bonadei has now left the ICRC and for the first time she speaks publicly about the accusation.

Sylvianne Bonadei: Of course it has affected me very much. I think in my own personality first of all, and then I had all that distress of being accused and not being able, you know, to let those people know that, "No, I wasn't in that plane."

DAVIS: Sylvianne believes that the people of Geselema are telling the truth, but that a white soldier impersonated her in the attack.

Sylvianne Bonadei: Of course, when you look back and you think military strategies and you think, "OK, how could have it been happening?" of course you can understand that yeah, that was an easy way to get back in there, because the local population could recognise our chopper from far away and every time we were landing everybody was around. I mean it was even sometimes dangerous for the pilot to land because there would be people everywhere.

Q: They trusted you?

A: They, yeah, they trusted us very much.

DAVIS: But were there any white soldiers present in West Papua at the time? Not according to the official account, but the official account has hidden 


\section{MARK DAVIS}

the truth for three years.

$\mathbf{Q}$ (to Daniel Start): Did you ever ask whether it was the British who were on board the helicopter?

A: No, I don't, we didn't. There wasn't really any need to.

Q: Did you assume it was them?

A: We assumed they'd been involved.

Q: And what was that assumption based upon?

A: It was based on this, on what reliable people had told us about white helicopters and white people, and particularly on what the Kopassus troops told us when we were rescued.

Q: What did they say?

A: Just simply that there were British troops around, or British people around, or actually white people around.

Q: Around?

A: They said: "Some of your guys around here."

Ivor Helberg: This is a picture of myself and General Probowo. He worked on advice from people like myself, and this was you know, on a, not just on a daily basis. I mean we were virtually living cheek by jowl, as you can imagine, the whole time.

DAVIS: The British have acknowledged that Ivor Helberg had a team of police hostage experts working with him, but it now appears that he had far more men at his disposal.

Ivor Helberg: You should understand that obviously, I must be careful because obviously I'm ... I've been a service person.

Q: Yeah?

A: And people that I've operated with, I'm, you know?

Q: Yeah?

A: They're people who, you know, I must make absolutely sure they don't in any way, you know, they're not put in jeopardy or anything of that sort. I don't think you understand that.

DAVIS: Witnesses claim that Ivor Helberg had a team of British SAS operatives working with him in the final weeks of the operation. It is a claim he does not deny. It is also claimed that the British provided sophisticated surveillance equipment, including this pilot less drone (UAV), to the operation. This and other technology requires specialized military operators and it appears that the British engaged a team of subcontractors to work under Helberg. It's still unclear exactly who those military subcontractors were.

18 PACIFIC JOURNALISM REVIEW 6:12000 
Ivor Helberg: Of course we use UAVs and all sorts of things. Those stories are perfectly true and in any situation you want to use every single bit of advice, every single bit of kit, and it's very difficult to, it's very easy shall we say to confuse, you know, actually what is advice and, "Oh my goodness, they're deeply involved you know - Executive Action, DSL, you know, Sandline, all these people."

DAVIS: Colonel Helberg is referring to groups of mercenaries.

Executive Outcomes Promotional Video: Hi, I'm Gavin and I work for Executive Outcomes and I've been working for them for a long time now...

DAVIS: One of these groups is Executive Outcomes seen here at work in Africa, were discovered in Papua New Guinea in 1997 about to launch a military attack on a group of landowners who had occupied Rio Tinto's Bougainville mine. But it wasn't the South Africans' first visit to the region.

File footage of Nick Van Den Berg: Executive Outcomes can offer probably a military solution.

DAVIS: For the first time former chief of Executive Outcomes, Nick Van Den Berg has confirmed that he led a team of five mercenaries in West Papua during the hostage crisis, providing advice and training for a helicopter assault team. He denies that he or his men flew on the helicopter that attacked Geselema. Van Den Berg also confirms that British SAS were in the area and he can identify two of them by name. The presence of EO and the SAS has been kept secret for the past three years, and according to Van Den Berg, there's even more white soldiers floating about the scene. It's a story that Helberg also confirms.

Ivor Helberg: We had advisers, and you would expect that. Advisers not only on you know, special operational procedures, but also on equipment that we might use and you know, we had to be open to this. And we also had a whole lot of people, as you can imagine a situation like that had been going on and on and on, we had a lot of people there who were offering their advice - for good money as you can imagine-mercenaries and others who came in from all kinds of things.

Q: And they turn up in Irian Jaya ...

A: $O h$, yes.

Q: ... offering their services?

A: Oh, yes. Oh, there was no shortage of that, but there is in my view anyway, and I cannot imagine that either the Indonesian government or Her Majesty's Government as far as our hostages are concerned, would allow some third party, mercenary organisation, to actually execute the kind of operation 


\section{MARK DAVIS}

on our behalf. I mean, can you imagine if it all went wrong? It would be horrendous, wouldn't it? What would the parents think and that sort of thing?

DAVIS: For the Papuans, the military operation did go horrendously wrong, but their version has never been believed and almost a photographic standard of proof has been required of them. In an Indonesian archive we found these images. This footage was shot inside Keneyam, General Probowo's military base in West Papua. It was filmed in the week of the attack upon Geselema. It records the Indonesian Kopassus unit which conducted the attack - and it reveals a white soldier, or perhaps he is just one of the numerous trainers and advisers that we now know were there. A white adviser who wears the full battle uniform of a Kopassus soldier. A white adviser who carries a sub-machine gun.

Silas Kogoya (singing): In the village of Geselema, what happened, what happened?

DAVIS: The village of Geselema, May 8th, 1996. The ICRC has invited people from across the Highlands to a large feast to celebrate International Red Cross Day and the release of the hostages. Within 24 hours some of these villagers will be dead. The three main members of the ICRC team are present: Dr Ference Mayer, responsible for the health of the hostages; Sylvianne Bonadei, fluent in Bahasa, she has become the most important member of the team; and the head of the Indonesian office, Henri Fournier.

Henri Fournier: I still remember that everything was so well and fine, the sun was there. Nothing could have allowed us to think that it would not be a happy ending, and still today I don't understand why Mr Kwalik changed his mind during the speech.

DAVIS: What went wrong on May 8 is central to what occurred the following day, but it too has been shrouded in mystery. The ICRC have a video recording of the 8th and other earlier events which they refuse to release. Four Corners has now obtained a copy of the tape. It would seem that this video was not shot as a Red Cross home movie - Kwalik claims he was told it was to ensure that his messages would reach the outside world.

Kelly Kwalik (in ICRC video of May 8): There has been so many tortures, rapes, intimidation and kidnappings, they cannot be counted.

DAVIS: Kwalik knew from radio reports that none of his statements were ever released. By May $8 \mathrm{Kwalik}$ had become suspicious that the International Red Cross were as intent upon muzzling him as the Indonesians were.

Kelly Kwalik (in ICRC video of May 8th): If people had any understanding 20 PACIFIC JOURNALISM REVIEW 6:1 2000 
BLOOD ON THE CROSS

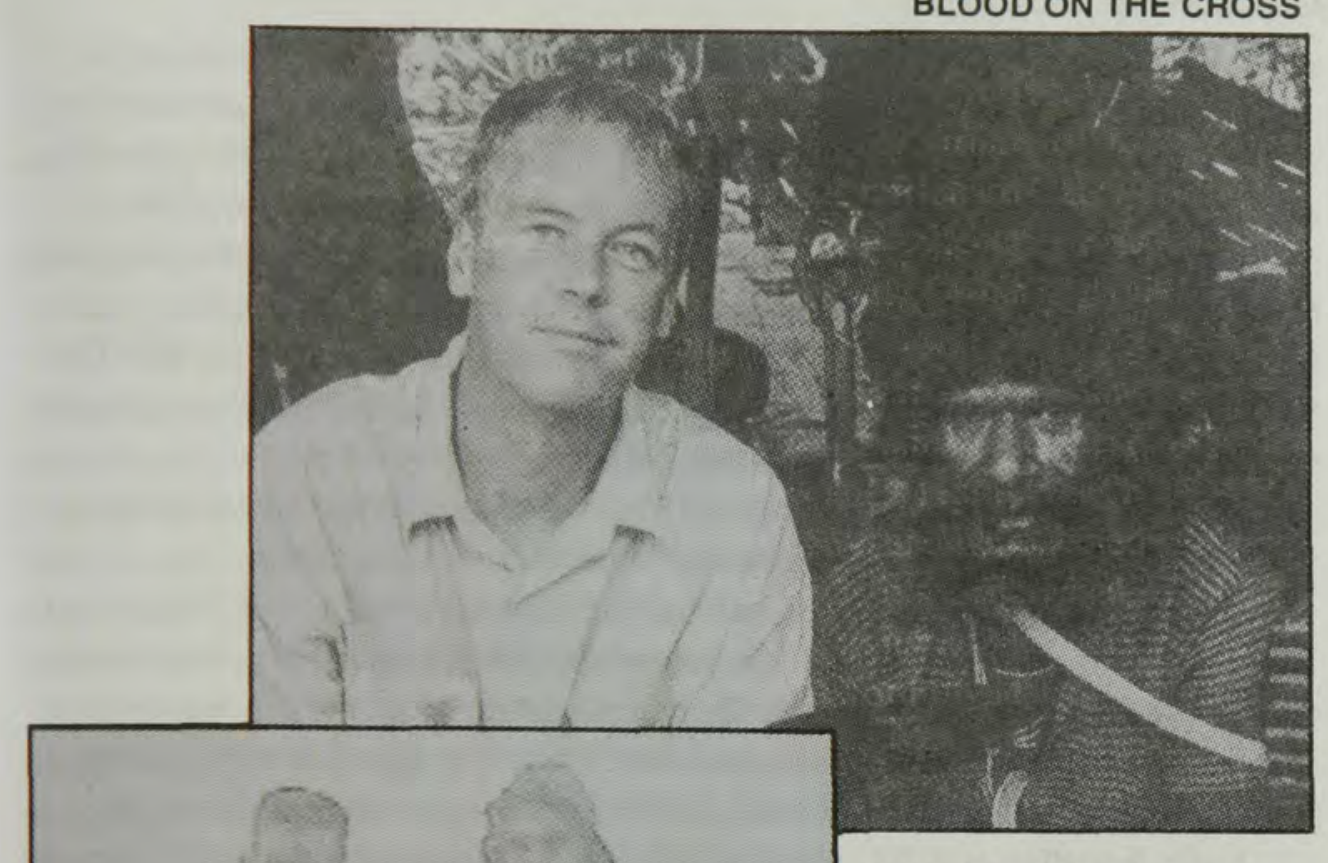

Top: Mark Davis and Kelly Kwalik at an OPM base in West Papua.

Left: An Indonesian Kopassus soldier with a white man dressed in full Kopassus gear in Kenyam, West Papua, May 1996, as shown on the ABC Four Corners' programme "Blood on the Cross".

ABC FOUR CORNERS 
of what has happened to us they would have to feel sorry for us.

Ivor Helberg: Unfortunately although everything was put into motion, Kelly Kwalik made a speech, at the very last moment he said, "We'll have no dealings with, we're going to go into the forest and these people will die."

DAVIS: Helberg wasn't there on the 8th. His version of what Kwalik said is not correct, but whatever impressions he was given would clearly have influenced decisions he made or advice he gave on the evening of the 8th. This video confirms eyewitness accounts that Kwalik made no threats whatsoever to the lives of the hostages, but he was angry.

Kelly Kwalik (in ICRC video of May 8): Even though we wear penis gourds and torn shirts, we have the brains God gave to us all.

DAVIS: Kwalik had agreed to hand the hostages over to the British and Dutch officials so he could talk to them directly, but the emissaries that arrived from those countries came from the Red Cross not the Government. He doubted that they would release his messages either. Were they just part of an elaborate Red Cross pantomime like the staff who were posing as news cameramen?

Kelly Kwalik (in ICRC video of May 8th): Is this really the Red Cross or people disguised as the Red Cross?

DAVIS: Kwalik suspected that the Indonesians would attack as soon as he handed over the hostages. He and his people would be killed and still their message would not have gotten out. He announced that the hostages would not yet be released, but did not close off negotiations. It was agreed that the ICRC team would return the next day, but the failure of the 8th had been a bitter and humiliating blow for them. Witnesses state that Henri Fournier was in a rage when he left the mountain and flew down to report to General Probowo and the Dutch and British representatives in Timika.

Ivor Helberg: This is something you need to talk to Henri about. He felt that he had been betrayed, by in this case the OPM, by Kelly Kwalik. He felt that there was nothing else that he could do usefully. So he decided that you know, he'd done what he could, he was terribly sad, as we were, and it really ... we realised that we were actually into a military operation.

DAVIS: As Helberg and Probowo considered their options for a military operation they faced a unique foe.

Ivor Helberg: Of course, they would know if somebody was in the area because they watch the birds and the reaction of the wildlife.

DAVIS: The terrain around Geselema is so extreme that helicopters were the only practical option, but tactically they had problems as well. 
BLOOD ON THE CROSS

Sylvianne Bonadei: They can even recognise the noises before the helicopter is in their view. They can say which ones are the choppers that we were using and the one that the army were using.

DAVIS: So how does the Probowo plan on getting helicopters close enough to Kwalik to eliminate his fighters and pluck out the hostages?

Map: Flight paths between Timika, Geselema and Keneyam at 7.00 am.

DAVIS: Seven am on the morning of the 9 th - Sylvianne Bonadei and Dr. Mayer leave Timika and fly to Geselema as arranged the day before. The doctor's task is to check on the health of the hostages. Sylvianne's responsibility is to talk with the OPM leaders. Meanwhile Henri Fournier flies to Keneyam military base and waits with General Probowo. Fournier claims that at 11.30 after speaking with Sylvianne and Mayer he officially advises Probowo that the mission of the International Red Cross has finished.

Henri Fournier: My conclusion is that while I was - we were involved the terms of the principle of the ICRC movement was well respected. As of the 9 th of May at around 11.30 in the morning local time there we were no more involved and I made it known to everybody.

DAVIS: The ICRC point to this press release issued in Geneva as evidence that they gave broad notice of their withdrawal at approximately 11.30. But they now admit that this release wasn't issued until after 3.00 o' clock - after the first shots were fired in Geselema - and of course the people there had no means of receiving it anyway.

Silas Kogoya (singing): The place of the boss of the Red Cross. What's it like? What's it like?

DAVIS: Both Henri Fournier and his boss Jean-Michel Monod still claim that notice was given - notice given by Sylvianne when she went to Geselema in the morning to take what they claim was a final offer: "Release the hostages now or the ICRC would withdraw immediately."

Jean-Michel Monod: You know we came back from this meeting on the morning of the 9th and we did not, we brought the answer back. The answer was, "No."

DAVIS: So the OPM effectively received notice when they rejected the offer and ended the negotiations - or did they?

Q to Sylvianne Bonadei: So that was, it was clear that the negotiations hadn't ended, that you were going to come back?

A: Oh, yeah, nothing had ended, even Kelly had never said, "It's finished." Never, ever he mention that. 
Q: And you'd never said it's finished?
A: No.

Q: You never took the message that, "This is the last ...

\section{A: No.}

Q: ... chance and if you don't do it now we're pulling out'?

A: No.

Q: So they didn't know that the ICRC was leaving, basically, at that point?

A: Well they only thing they knew was that we were flying back and we would come back on, at least try to come back, on Sunday. So I don't know how many days it is in between, but I remember clearly that we left them saying that it would be a Sunday. Of course they have always had behind their mind that the army might come in.

DAVIS: Daniel Kogoya spent three hours talking with Sylvianne and Dr. Mayer on the morning of the 9th. He was sure that the saga was about to end, that he and Silas could talk Kwalik into releasing the hostages in three days' time when Sylvianne had said she would return. Dr. Mayer still works for the ICRC and he will not comment about the events of this day.

Map: Flight path between Geselema and Keneyam at $11.20 \mathrm{am}$.

DAVIS: As Sylvianne left Geselema to meet with Probowo and Fournier at Keneyam she thought she was bringing good news, that there was still hope of. a release. There was no discussion about ending the mission. Sylvianne's account raises serious doubts about the ICRC's version of events for the last three years. She confirms that the OPM did not know that they were withdrawing on the 9th - and neither did she.

Q to Sylvianne Bonadei: So can we just make this absolutely clear? Were you aware that the negotiations had ended on the, at midday on the 9th of May?

A: No, I was not aware. I remember very clearly that we said that our next commitment with them was we would try to go back there on the Sunday.

DAVIS: So as Henri and his team leave Keneyam and arrive in Timika at 1:30, it would seem that the only people who do know what his plans are, are General Probowo and at least some of his numerous white advisers.

Major-General Probowo: God be with us.

DAVIS: The withdrawal of the International Red Cross without notice to the Papuans gave Probowo a unique but narrow window of opportunity. The story of the ICRC's departure was bound to be out and on the radio by the next day, then it would be too late to send in a Trojan horse draped in a Red Cross flag. The scheme had to occur that afternoon. As Probowo's choppers take off at 24 PACIFIC JOURNALISM REVIEW 6:1 2000 
around 2:30, Henri Fournier and Dr Mayer are getting ready to catch a plane to Jakarta. Sylvianne still doesn't know that the mission is over.

Q to Sylvianne Bonadei: So when Henri left on the afternoon of the 9th he hadn't told you that the mission was over? As far as you were concerned the mission was still continuing?

A: Yeah, for me, I still had in mind that we had to try to get back there.

Q to Henri Fournier: Are you trying, are you taking your team back to Jakarta so that you're not around?

A: Well I mean that if, not really, but I mean that if the military option had to be accepted by everybody, I was not to be part of it anyway because it was not. I had no advice to give in this kind of a situation.

DAVIS: For three years the International Red Cross have distanced themselves from the events of the afternoon of the 9 th. They claim that officially they were no longer involved so it had nothing to do with them. And it certainly seems important to Jean Michel Monod that his team had left the island as well.

Q to Jean Michel Monod: What are your staff doing on the afternoon of the 9 th?

A: Well they were certainly not in a helicopter as the rumor has it. Some were on their way back, or I suppose they were all on their way back to Jakarta.

Q: They were all on their way back to Jakarta?

A: Yeah.

Q: So, well who was that? Who was going, on their way back to Jakarta at the time? Sylvianne Bonadei wasn't going back to Jakarta.

A: She was going back to Jakarta.

Q: No, she wasn't.

A: Yes, of course she was.

Q: Henri says she wasn't.

A: Henri says she wasn't? Why she, what was she doing back in Timika?

Q: I don't know, I was hoping you might tell me. That's, it is a mystery. What was she doing in Timika? She was there for another two days.

A: Are you kidding me?

Q: No, ask Henri. Henri left at 3 o'clock and Dr. Mayer left at 3 o'clock on their flight to Jakarta, and Sylvianne remained.

DAVIS: As Fournier and Dr Mayer wait to catch their plane for Jakarta, a white helicopter approaches Geselema with five military helicopters well behind it. But the hostages are no longer in Geselema, nor are the OPM - they had moved camp about a kilometer down the hill. 


\section{'Daniel fired back,} but missed ... The people were scattered everywhere. Five minutes later helicopters from the Indonesian airforce came and started shooting and dropping bombs in

\section{Geselema.'}

\section{Institute for Human} Rights investigator
Daniel Start: On the afternoon of the 9th Silas had came to camp and he was going on, you know, "We'll get you out of here, we'll get you, we'll sort something out." And it was while he was saying this and we'd all gathered around and we were nodding enthusiastically, that we heard this helicopter coming across the mountains. "Red Cross, "we said, "Red Cross," you know. And Silas looked around and, "OK, yeah, Red Cross."

DAVIS: There were only three or four OPM members in the village as the chopper approached. The civilians included guests from across the mountain who' $d$ been invited to the ICRC feast in Geselema the day before. They had nothing to do with Kwalik, the OPM or the hostages. For them the Red Cross helicopter was always a welcome sight and they stepped forward eagerly to greet it.

Institute for Human Rights investigator: At 3o'clock a white helicopter came with the Red Cross flag with white skinned people on board. Then about one meter before landing they jumped and fired in the squatting position.

Daniel Kogoya: Once they'd jumped out we did not recognize them, only Sylvia, a lady. Straightaway she said, "There is Daniel Yudas." Then she moved one step ahead. She waved towards me and then squatted down facing me. And those Western people had laid face down and the shooting continued.

Institute for Human Rights investigator: Daniel fired back, but missed.

Daniel Kogoya: Then I shot at Sylvia. I don't know if she died, but my message was: "We've looked after the hostages and were about to hand them over, so why did you use violence?"

Daniel Start: And then about five minutes later there was a crack like a tree falling, and then we realized it was gunfire.

Institute for Human Rights investigator: The people were scattered everywhere. Five minutes later helicopters from the Indonesian airforce came and started shooting and dropping bombs in Geselema. 
Photo: Papuan woman.

Institute for Human Rights investigator: She was one of the wounded in the shooting in Geselema and an eyewitness of the shooting of her friend.

DAVIS: The Human Rights report confirms that at least eight civilians were killed on the 9th of May in Geselema. Many more were wounded, and others are still missing, suspected dead.

Photo: Papuan boy.

Institute for Human Rights investigator: This is one of the boys whose mother was shot in Geselema, and his sister was taken away by the soldiers and disappeared.

Ivor Helberg: What I can say to you is that the SAS were not used in this operation.

DAVIS: Helberg adds that no other British troops were used either and that he was out of the province at the time of the attack. And yet when Britain has been so intimately and publicly associated with the lead up to that day, why have they displayed virtually no interest in discovering what really occurred?

What did their surveillance and monitoring equipment reveal on the 9th? And why not use that information to redeem Britain's reputation, in West Papua if nowhere else? Do their tapes identify who opened fire on the civilians of Geselema? Do they reveal the identity of the white helicopter? The witnesses identify the helicopter as a Bell 412 or 212 , white with markings. This matches some of the helicopters that had been provided by, Freeport through it's contractor Airfast to the International Red Cross during the negotiations. In fact they are the only helicopters that are permanently based in the region that match the descriptions. Airfast and Freeport deny that any of their helicopters, whether owned or chartered, were used in the attack. Airfast opens its logs to indicate that their craft were not being used on the afternoon of the 9 th, but there are still some oddities.

Q to Airfast representative: So on the 9th, what's it doing flying 12 people, have you got any recollection?

A: Wouldn't have a clue.

DAVIS: There are several flights during the relevant period which indicate that the military did use Airfast Bell $412 \mathrm{~s}$ or $212 \mathrm{~s}$. On the mornings of the 8th and the 9th there are also two flights of unknown purpose which had 12 people and 100 kilos of load hovering in the valleys immediately next to Geselema. Is it possible that they are 12 soldiers carrying weapons and ammunition?

Ivor Helberg: You know the helicopters as far as I'm concerned we used 
were military helicopters. Yes, there was a white helicopter which actually belonged to Freeport that was used which was sculling around, but as far as I'm aware, as far as I'm concerned, you know, the Red Cross was taken off the minute the Red Cross went out of the country.

DAVIS: Did the International Red Cross make any inquiries whatsoever into the movements of the helicopters that had been booked in their name? And why such a languid response by the ICRC to one of the most serious abuses of its symbol imaginable? It seems implausible for either the ICRC or the British to plead ignorance on these matters.

Photo: Front of Daniel Start's book, The Open Cage: The Ordeal of the Irian Jaya Hostages.

DAVIS: At the very least Daniel Start printed the essence of the story in his account of his time as a hostage which was published two years ago. Daniel confirmed the scale of the attack which he heard but didn't see. But many of the local people who were fleeing with him for the next six days did see it and spoke about it.

Daniel Start: And suddenly we were terrified, because up until now the white people were the good guys.

DAVIS: The events of May 9 were some of the briefest accounts in his book and he says the hardest to write.

Q to Daniel Start: Have you been told not to talk about what you know about the situation?

A: We were certainly told that operations like this have to be carried out in secrecy and it's important that the details are not known because if they are they jeopardise future operations. That's what we were told. And it was, you know, a gentleman's agreement that whatever we might have picked up while we were in the forest shouldn't really be talked about.

Photo: Front of Daniel Start's book, The Open Cage: The Ordeal of the Irian Jaya Hostages.

DAVIS: There is a certain coyness in some of the passages, but the message was clear enough: "Was it possible that white people, British people, perhaps, had been a part of that first attack? Was it possible that they had commandeered an Airfast helicopter and pretended to be the Red Cross?" Open questions that were never answered, suspicions broadly held across West Papua that have never been dispelled.

Henri Fournier: Look, I cannot remember it exactly, but I can tell you that this story of a white helicopter came to my knowledge most probably to say the 28 PACIFIC JOURNALISM REVIEW 6:1 2000 


\section{BLOOD ON THE CROSS}

least, two months afterwards. I mean I never receive any information just, such as the one you are telling me now, until I received the visit of somebody from Irian who talked to me about it.

Q: You must have known this within days, I mean the hostages were talking about this?

A: I don't recall that and I, I'm, I don't recall having, you know, first of all we didn't, I don't recall having been told by the hostages about it.

Daniel Start: There was no point in us telling the British officials what we knew - they knew. They knew perfectly, much better, what had happened. We talked to the Red Cross about it because it had a direct, direct implications for whether they could work in the area safely again.

Sylvianne Bonadei: For me, my first information that something strange happened was when I met Mark on the day of the, when the hostages arrived in Timika where Mark in tears just told me, "Why that white helicopter?" And I just was so stunned and I said, "What are you talking about?" And he couldn't say anything, he just said, "But why that white helicopter?" I kept telling them, "No, Imean, I wasn't there, it wasn't me. I can't believe it. I mean, just trust me, I wasn't in there."

Institute for Human Rights investigator: If they think they were not involved they should have been here to investigate and convince us that. To fulfill their humanitarian mission they have to find out if people have been killed.

\section{Q to Henri Fournier:}

Was one of the reasons this was not investigated to maintain good relations with the Indonesian military?

A: Not really.

Q: Would this have been a great embarrassment to the Indonesian military?

A: Not at all, because I mean it will have been very easy for everybody not to acknowledge it because there was nobody to bring evidence.

Q: Well there's hundreds of people up there who are prepared to give evidence.

A: Yeah, I know, but it's one side of the story.

Q: Well who's the other side of the story, General Probowo?

Q to Jean Michel Monod: Well what investigations did you make regarding this event?

A: Well of course we asked questions around. We asked questions to the Indonesian military and we shared our concern with the two embassies, British and Dutch embassy, and we never get any precise answer. Imean, the operation 


\section{MARK DAVIS}

took place, the hostages were released except for two Indonesian hostages who were killed, and that was it.

Sylvianne Bonadei: I don't really know what has caused that kind of a closed mouth and no wish for an inquiry actually, because if the emblem has been violated I think this is a very, you know, it was our only powerful means of getting into the, that place and get the trust from these people. So how can they possibly trust us again?

Papuans gathering food in jungle: Your faces will be in this camera. If you see some leaves on the other side, just grab them.

Mother with baby: Oh, poor girl. You poor girl. Let Mama pick the cassava.

DAVIS: If the Indonesian military learnt any lessons from the attack on Geselema it was that no one would ever know what they did in these hills, or that those that did know would never say. Silence has killed far more people here than those who were gunned down in Geselema.

Papuan woman: In the war my husband and my sister-in-law were killed by the army and they burned the houses. And now look, when I took my babies with me they were very small and now they're getting big.

DAVIS: A church report last year which managed to investigate just one small part of these mountains concluded that dozens of people had been raped and severely beaten, 16 killed and 120 died of starvation in the wake of the hostage crisis.

Papuan youth: They hit me on the head and smashed my face. That is why whenever I work hard the blood will come out of my mouth.

DAVIS: No one has any real idea of the full impact of the military operation across these mountains, partly because no one has ever asked.

Daniel Start: Nobody wants to stand up alone against the Indonesian military because they won't be allowed to stay, and a lot of people feel it's, you know, well either because they've got, you know, mining concessions there or because they feel they've got other work that they need to do which is more important, they've chosen to either ignore the information or to keep silent about it. And for the Papuans, whatever they shout, cry or scream, nobody's gonna listen, nobody can hear them.

DAVIS: These people are truly on their own. In their eyes it's not just Indonesians who want to see them dead. It's the Americans who want their gold, the British or the Dutch who send soldiers after them, the UN who gave away their land, and now they think the Red Cross has betrayed them as well.

Q to Jean Michel Monod: But what does that symbol, that Red Cross 30 PACIFIC JOURNALISM REVIEW 6:1 2000 


\section{Post-Courier}

.... more than just Papua New Guinea's number one daily since June 1969, the Post-Courier is the longest established news medium for all Papua New Guineans.

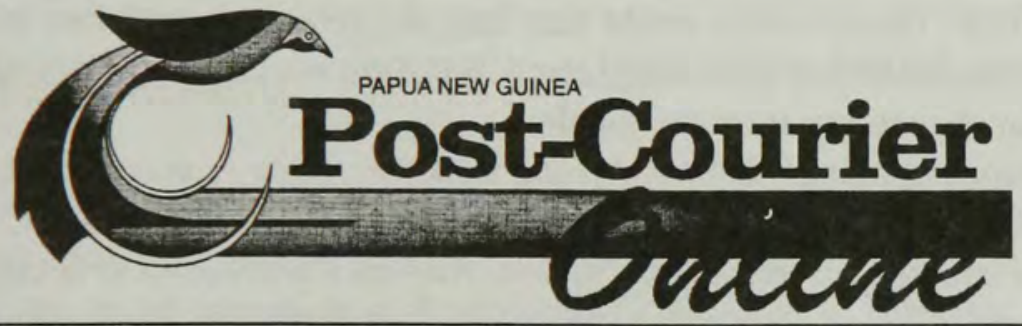

.... since February 1997, we've been online, to tell the world about our world. www.postcourier.com.pg

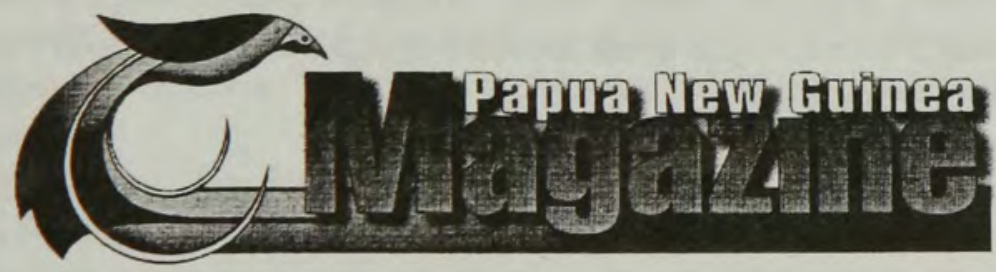

... a free colour magazine, every month in Post-Courier, established February 1998.

South Pacific Post Pty Ltd, PO Box 85, Port Moresby, Papua New Guinea Email: postcourier@ postcourier.com.pg Post-Courier Online www.postcourier.com.pg Tel: (675) 3091000 Fax: (675) 3200249 


\section{MARK DAVIS}

symbol, mean to you? What does it signify?

A: It's an emblem which is supposed to protect the wounded, the sick and those who care for them.

Q: And what do you think "emblem" means to the people of Irian Jaya now? killings.

A: Well if this story is really true, of course, this emblem is associated with

DAVIS: These men and boys are being taught how to face machine guns when they are armed with bows and arrows. The Ndugas, the Amungme and the Danis, hunted and alone, they say that this year is the time that they'll make their last stand.

Papuan youth: We are not the only ones talking on this matter. All the black skins in this place are saying the same thing.

DAVIS: There is little doubt that they are going to attack this year, and there's little doubt they'll be slaughtered. But if the world hears of it at all, it will be just another rumor from the jungle.

Papuans (singing): Before, I could walk free. Now I am confused. Where can I go? Every path I take, all I find is suffering. When I feel hungry. When I thirst for sweetness, it is too hard to find. We face a bitter path. It is the pain of us orphans.

$\square$ A transcript of the ABC TV Four Corners programme "Blood on the Cross", shown on 12 July 1999. Mark Davis investigated allegations about the role of the International Red Cross and the British military in a massacre in the Southern Highlands of Irian Jaya during May 1996. He won a Walkley Award for this report. Reporter: Mark Davis. Producer: Mark Davis. Researchers: Matt Brown, Peter Cronau. Email: bfmedia@mpx.com.au KABAR IRIAN ("Irian News") Website: http://www.irja.org/ 